J. Perinat. Med. $12(1984) 179$

\title{
Maternal serum alpha-fetoprotein (MSAFP) and fetal growth
}

\author{
F. G. Mariona, M. M. Hassan, F. N. Syner*, L. C. Chik**, R. J. Sokol
}

Department of Obstetrics and Gynecology, Division of Maternal-Fetal Medicine

* C. S. Mott Center for Human Growth and Development

** Medical Database Informatics

Wayne State University, Hutzel Hospital, Detroit, Michigan, USA

Maternal serum alpha-fetoprotein (MSAFP) is known to be elevated in fetal open neural tube defects (NTD) [5, 7, 21, 24]. It is used as an early screening method for this condition when measured between 15 and 20 weeks of gestation and is likely to become a routine part of prenatal care. It is also elevated in multiple pregnancies [23], fetal demise [18], threatened abortion [22] and other fetal abnormalities, such as omphalocele, fetal bowel obstruction [6], congenital nephrotic syndrome [17], trisomy 13 with cystic hygroma and TURNER's syndrome [13]. In the non-pregnant state, serum AFP is elevated in primary hepatoma [1], embryonal cell carcinoma of the ovary [12], ataxia telangectasia and hepatitis [19].

Elevated mid-trimester alpha-fetoprotein (MSAFP) in women carrying single, anatomically and karyotypically normal fetuses has been found to precede the birth of low birthweight infants. BROCK et al. [4], found that the proportion of low birthweight infants less than $2.5 \mathrm{~kg}$ was significantly increased when early mid-trimester MSAFP was greater than 2.3 ( $x$ median value). WALD et al. [25], demonstrated that pregnancies with early mid-trimester MSAFP greater than or equal to 3 ( $x$ median value), resulted in the birth of infants weighing on the average 357 gms less than the controls. Also, the gestational age at the time of birth was 8 days less than the controls. SMITH [20] on the other hand, found that a statistically significant increase in the number of infants weighing less than $2.5 \mathrm{~kg}$ in pregnancies whose early mid-trimester MSAFP values were greater than twice the median; these infants were appropriate but not small for gestational age.

None of the reported studies has examined the overall relationship, if any between early midtrimester MSAFP and neonatal birthweight and gestational age. The purpose of this study is to determine if such relationships exist and whether or not they may be useful in detecting risk for altered growth or preterm delivery.

\section{Materials and methods}

Venous blood was obtained from patients referred for genetic counseling prior to clinically indicated amniocentesis between 15 and 20 weeks gestation in the period between January 1980 and December 1982. Informed consents were obtained from all patients. Complete data including MSAFP values, neonatal birthweight, and estimated gestational age at birth were available in 116 pregnancies. Indications for genetic counseling are included in Tab. I. One hundred and ten karyotypically and anatomically singleton pregnancy outcomes were evaluated; six cases were excluded because of fetal demise ( 3 cases), trisomy 21 (1 case), trisomy $X$ ( 1 case), twins ( 1 case). 
Tab. I. Indications for genetic amniocentesis

\begin{tabular}{lr}
\hline Indication & Number \\
\hline Maternal age $<35$ & 102 \\
Family history of NTD & 3 \\
Family history of DOWN's Syndrome & 3 \\
Parental sickle cell disease & 3 \\
Family history of mental retardation & 2 \\
Previous sibling with chromosomal abnormality & 1 \\
Maternal anxiety & 1 \\
Major fetal anomalies by ultrasound & 1 \\
\hline Total & 116 \\
\hline
\end{tabular}

MSAFP was determined by radioimmunoassay (RIA) and values were expressed as multiples of the median (MOM) [16].

Gestational age at amniocentesis was calculated from ultrasonic examination of the biparietal diameter and femur length. Gestational age at birth was estimated using the BALLARD modification of the DUBOWITZ examination of the neonate [2].

Statistical analysis utilizing polynomial and multilinear regression was performed to determine the relationship of MSAFP values between 15 and 20 weeks gestation, expressed as multiples of the median (MOM), to the neonatal birthweight, gestational age at birth and birthweight adjusted for gestational age. A p less than .05 was considered significant.

\section{Results}

The mean gestational age at the time of sampling was $16.8 \pm 1.2$ weeks; the mean gestational age at birth was $39.6 \pm 2$ weeks; the mean birthweight was $3436 \pm 654 \mathrm{gms}$. The MSAFP values ranged from .19-3.1 multiples of the median. These values are presented in Tab. II in detail.

Using polynomial regression we found that, according to the equation - Birthweigt (gms.) $=-332 \mathrm{AFP}+3748$, the birthweight decreased 322 grams for each one MOM increase of MSAFP. For this relationship, $\mathrm{R}=.234$ and $\mathrm{p}<.02$. There was no improvement in the strength of this relationship (or of any of the other tested relationships) beyond the linear fit.

A relationship of MSAFP to birthweight could be accounted for by an effect of pregnancy duration, fetal growth or both. To examine this possibility, multilinear regression analysis was utilized. It was found that MSAFP values between 15 and 20 weeks gestation related to birthweight adjusted for gestational age ten-fold more strongly $\left(R^{2}=6.3 \%\right.$, $\mathrm{p}<0.01)$ as shown in Fig. 1 than to gestational age alon $\left(\mathrm{R}^{2}=.6 \%\right.$, NS). Gestational age at amniocentesis was unrelated to fetal growth or pregnancy duration.

\section{Discussion}

This study demonstrates that there is a definite linear relationship between early mid-trimester MSAFP values and fetal growth, a mainly third trimester phenomenon. Early mid-trimester MSAFP values were not significantly related to gestational age at birth.

Our study differs from those previously reported $[3,4,20,25]$, in that all babies were included, so that any overall relationships could be detected, rather than simply to correlate their birthweight with early mid-trimester MSAFP values relating elevated MSAFP values to low birthweight. The majority of patients in this study were referrals

Tab. II. Values obstained in the current study

\begin{tabular}{lrrrr}
\hline Variable & Range & & Mean & Standard deviation \\
\hline MSAFP (ng/ml) & $4.80-87.30$ & 31.68 & 16.44 \\
MSAFP (MOM) & $0.19-3.11$ & 1.04 & 0.50 \\
Gestational age (weeks) & $30.50-42.50$ & 39.61 & 2.03 \\
Birthweight (grams) & $1230.00-4990.00$ & 3436.30 & 654.38 \\
Birthweight adjusted for gestational age (percentile) & $0.0004-99.78$ & 67 & - \\
\hline
\end{tabular}




\section{Birth Weight Adjusted for Gestational Age $\%$}

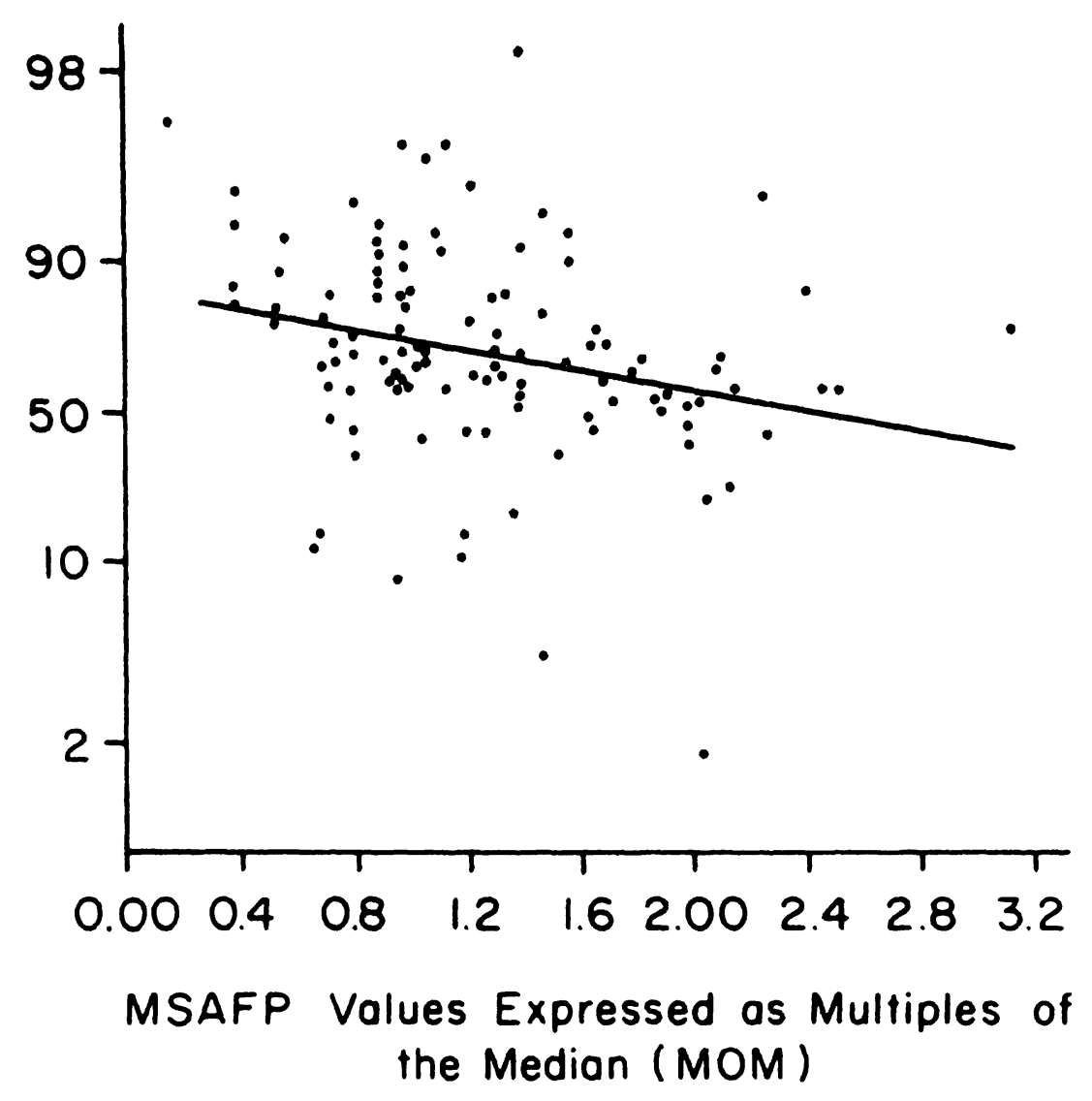

Fig. 1. Relationship of MSAFP values expressed as MOM to birthweight adjusted for gestational age.

(40 patients from our institution) for genetic counseling. They were, in general, not at increased risk for intrauterine growth retardation (IUGR). This is reflected in the distribution of their outcomes - 85 appropriate for gestational age, 22 large for gestational age, and 3 small for gestational age.

The explanation for the key finding in this study remains speculative AFP is a predominant protein in fetal plasma and it reaches its highest concentration [9] at 12-15 weeks gestation. It is synthesized in the fetal liver [8] and the embryonal sac [10]; it passes by diffusion into the fetal urine and is excreted into the amniotic fluid. Some of the amniotic fluid AFP diffuses into the maternal circulation through the amnion while some is swallowed by the fetus. As pregnancy progresses, an increasing portion of the maternal serum AFP is derived by placental passage. While the amniotic fluid AFP declines as gestation proceeds, the level in maternal serum rises geometrically until 32 weeks when it begins to fall [9].
Nonetheless, the elevation of serum AFP in primary liver cancer in non-pregnant patients has been attributed to its increased production from undifferentiated cells [15]. Raised levels in nonmalignant liver disease during the recovery stages seems to be associated with regeneration of the liver cells; both in experimental liver damage in mice and after cessation of alcohol intake in cirrhotic patients, AFP levels have been found to be elevated [4]. This might offer an explanation for elevated early mid-trimester MSAFP and altered fetal growth; the liver is the first organ to be affected in growth retarded fetuses. This could be associated with a protective mechanism, in the form of multiplication or relatively undifferentiated embryonic cells which would produce increased amounts of AFP. This hypothesis could and should be tested.

An alternative hypothesis to explain the relationship between MSAFP and fetal growth could be based on the observation of spontaneous fetalmaternal hemorrhaging and elevated early mid- 
trimester maternal serum alpha-fetoprotein, as reported by HAY [11]. We are currently examining this possibility.

Regardless of the precise mechanism, it is reasonable to conclude from the current results that early mid-trimester MSAFP determinations, likely to become a routine part of prenatal care for NTD screening, may also be of assistance in identification of fetuses at risk for altered growth. Early mid-trimester MSAFP does not appear to aid in the detection of preterm or postterm births. The utility of maternal serum alpha-fetoprotein for the antenatal detection of IUGR deserves further study.

\section{Summary}

Early mid-trimester screening of maternal serum alphafetoprotein (MSAFP) for the detection of neural tube defects is becoming a routine part of obstetrical care. In singleton pregnancies in the absence of fetal chromosomal abnormalities and anatomical anomalies high levels of AFP have been variably related to increased risk for low birthweight infant outcome. The overall relationship, if any, of maternal serum AFP to infant birthweight has, however, not been previously characterized. Between 15 and 20 weeks gestation, MSAFP values were determined for 110 women carrying single, anatomically and karyotypically normal fetuses. Statistical analysis utilizing polynomial and multilinear regression was used to deter-

mine the relationship of early mid-trimester MSAFP first to neonatal birthweight and then to gestational age and birthweight adjusted for gestational age. For every increase of one multiple of the median in MSAFP, neonatal birthweight fell 322 grams. This was accounted for almost entirely by decreased fetal growth; early midtrimester MSAFP was linearly related to birthweight adjusted for gestational age ten times more strongly than to gestational age alone. The explanation for this relationship remains speculative, but the utility of routine AFP screening for the antenatal detection of intrauterine growth retardation certainly deserves further study.

Keywords: Alpha-fetoprotein, birthweight, gestational age, intrauterine growth retardation.

\section{Zusammenfassung}

Alpha-Fetoproteinspiegel im mütterlichen Serum(MSAFP) und fetales Wachstum

Die Alpha-Fetoproteinbestimmung zu Beginn des zweiten Schwangerschaftstrimenon zwecks Diagnose von Neuralrohrdefekten scheint $z u$ einer Routinemaßnahme in der Geburtshilfe zu werden. Bei Einlingsschwangerschaften ohne chromosomale und morphologische Anomalien wurden wiederholt hohe Alpha-Fetoproteinspiegel in Zusammenhang mit einem erhöhten Risiko für ein niedriges Geburtsgewicht gebracht. Wenn es überhaupt diesen Zusammenhang $z$ wischen AFP und kindlichem Geburtsgewicht gibt, so ist er bislang nicht genauer charakterisiert. Wir bestimmten bei 110 Einlingsschwangerschaften mit karyotypisch und morphologisch normalen Feten die MSAFP-Werte $z$ wischen der 15. und 20. Schwangerschaftswoche. Mit Hilfe der statistischen Bearbeitung unter Verwendung der polynomen und multilinearen Regressionsanalyse wollten wir erstens die Beziehung zwischen
MSAFP-Werten zu Anfang des zweiten Trimenons und dem Geburtsgewicht erfassen. Zweitens sollte die Beziehung zum Schwangerschaftsalter bzw. zum anhand des geschätzten Geburtsgewichtes korrigierten Schwangerschaftsalter charakterisiert werden. Jeder Anstieg des Medians der MSAFP-Werte um eine Einheit bedeutet eine Reduzierung des Geburtsgewichts um 322 Gramm. Dies wird nahezu vollständig durch eîn herabgesetztes fetales Wachstum erklärt. Die lineare Beziehung zwischen den MSAFP-Werten und dem auf das Schwangerschaftsalter bezogene Geburtsgewicht ist zehnfach strenger als im Vergleich zum Schwangerschaftsalter allein. Der Hintergrund für diese Zusammenhänge ist unklar. Es sollten jedoch weitere Untersuchungen $\mathrm{zu}$ der Fragestellung durchgeführt werden, ob ein routinemäßiges AFP-Screening zur Erfassung einer intrauterinen Wachstumsretardierung sinnvoll ist.

Schlüsselwörter: Alpha-Fetoprotein, Geburtsgewicht, Gestationsalter, intrauterine Wachstumsretardierung.

\section{Résumé}

Alpha fœto-protéine serique maternelle (MS $\alpha \mathrm{FP})$ et croissance fœtale

Le dosage de l'alpha-fœto protéine sérique maternelle (MS $\alpha \mathrm{FP}$ ) au début du second trimestre est devenu habituel dans la surveillance obstétricale afin de détecter les défauts de fermeture du tube neural. Au cours des grossesses uniques, en l'absence d'anomalies anatomiques, des taux élevés d' $\alpha \mathrm{FP}$ ont été de façon variable considérés comme témoins d'un risque élevé d'avoir un enfant de faible poids de naissance. Cependant, la relation globale entre $l^{\prime} \alpha F P$ maternelle sérique et le poids de naissance de l'enfant, si elle existe, n'a pas été caractérisée antérieurement. On a déterminé les valeurs de 1'MS $\alpha \mathrm{FP}$ entre 15 et 20 semaines gestationnelles chez 110 femmes enceintes d'un seul foetus, anatomiquement normal et avec un caryotype normal. Afin de déterminer la relation entre 
l'MS $\alpha \mathrm{FP}$ au début du second trimestre et d'une part le poids de naissance et d'autre part l'áge gestationnel et lo poids de naissance en fonction de l'áge gestationnel, on a effectué une analyse statistique utilisant une régression polynomiale et multilincaire. Le poids de naissance chute de 322 grammes pour chaque augmentation d'un multiple de la valcur moyenne d'MS $\alpha \mathrm{FP}$. Ce fait a cté justific presque entic̀rement par une diminution de la croissance fortale; le taux d'MS $\alpha F P$ du début de deuxième trimestre est corrélé de façon linéairo au poids de naissance corrigé en fonction de l'áge gestationnel seul. L'explication de cette rolation demeurc spéculative, mais l'utilité d'un dosage $d \alpha F P$ en routine pour la détection antenatale du retard de croissance intra-utérin mérite à coup sûr unc étude supplémentaire.

Mots-clés: Age gestationnel, $\alpha$-fœto-protéine, poids de naissance, retard de croissance intra-utérin.

\section{Bibliography}

[1] ALPERT, M.E., J.URIEL, B.D. E.NECHAUD: Alpha1-fetoglobin in the diagnosis of human hepatoma. N. Eng. J. Med. 278 (1968) 984

(2) BALLARD, J. L., K. NOVAK, M. DRIVER: A simplified store for assessment of fetal maturation of new. born infants. J. Pediat. 95 (1979) 769

13] BROCK, D. J. H., L. BARRON, P. DUNCAN et al.: Significance of elevaled mid-trimester maternal plasma alpha-fetoprotein values. Lancet i (1979) 1281

14] BROCK, D.J.H., L. BARRON, P.JELEN et al.: Muternal serum alpha-fetoprotein measurements as an early indicator of low birth weight. Lancet ii (1977) 267

[5] BROCK, D. J. H., J. B. SCRIMGLOUR, J. STEVEN et al.: Maternal Plasma alpha-fetoprotein screening for fetal neural tube defects. Br.J. Obstet. Gynaecol. 85 (1978) 575

[6] CLARKE, P.C., Y.B. GORDON, M. J. KITAN ot al.: Alpha-fetoprotein levels in pregnancies complicited by gastrointestinal abnormalities of the fetus. Br. J. Obstel. Gynuccol. 84 (1977) 285

[7] FERGUSON-SMITH, M. D., H. A. RAWLINSON, H. M. MAY et al.: Avoidance of anencephalic and spina bifida births by maternal scrum alpha-fetoprotein screening. Lancet ii (1978) 1330

[8] GITLIN, D., M. BOESMAN: Sites of serum alphafetoprotein synthesis in the human and in the rat. J. Clin. Invest. 46 (1967) 1010

19] GITLIN, D., M.BOESMAN: Scrum alpha-fetoprotein, albumin and gamma-G globulin in the human conceptus. J. Clin. Invest. 45 (1966) 1821

[10] GITLIN, D., A. PERRICELLI: Synthesis of serum albumin, prealbumin, alpha-fetoprotcin, alpha-1antitrypsin and transferrin by the human yolk sac. Nature 2 (1970) 995

[11] HAY, D. L., J. U. BARRIE, G. B. DAVISON et al.: The relation between maternal serum alpha-fetoprotein levels and fetomaternal hemorrhage. Br. J. Obstet. Gynecol. 86 (1979) 516

[12] KITHIER, K. J. LUSTER, J. BROUGH ct al.: Effect of therapy on the level of alpha-fetoprotein in cmbryonal cell carcinoma. J. Pediat. 81 (1972) 71

[13] MILUNSKY, A. (ed.): Genetic disorders and the fetus: diagnosis, prevention and treatment. Plenan, New York 1979.
(14) RUOSLAHTI, E., M. SA LASPORO, H. PIHKO ct al.: Scrum alphil-fetoprotein: diagnostic significance in liver diseasc. Br. Med. J. 393 (1974) 527

[15] RUOSLAHTI, E., M. SEPPÄLÄ: Studics of carcinofetal proteins and development of a radioimmunoassay for-fetoprotein. Demonstration of-fetoprotein in serum of healthy human adults. Int.J. Cancer 374 (1971) 8

[16] RUOSLAH'T, E., M.SEPPÄL, Ä: Handbook of Radioimmunoassay. G. ABRAHAM (editor) Marcell and Dekker, New York (1977) 543

117] SEPPÄLÄ, M., P. AULA, J. RAPOLA ct al.: Congenital nephrotic syndromc: prenatal diagnosis and genetic counselling by estimation of amniotic fluid and maternal serum alpha-fetoprotein. Lancet ii (1976) 123

[18] SEPPÄLÄ, M., E. RUOSLAH'TI: Alpha-fetoprotein in maternal serum: a new marker for detection of fetal distress and intrauterine death. Am. J. Obstet. Gynecol. 48 (1973) 115

[19] SILVER, H. K. B., J. DENEAULT, P. GOLD et al.: The detection of alpha-fetoprotein in patients with viral hepatitis. Cancer Res. 34 (1974) 244

[20] SMITH, J. L.: Raised inaternal serum alpha-fetoprotein Levels and low birthweight babics. Br. J. Obstet. Gynaccol. 87 (1980) 1099

[21] United kingdom collaborative study on alpha-fetoprotein in relation to neural tube defects. Lancel $i$ (1977) 1323

[22] WALD, N., S. BARKER, H. CUCKLE et al.: Maternal scrum alpha-fetoprotein and spontaneous abortion. Br. J. Obstet. Gynaec. 84 (1977) 357

[23] WALD, N.J., S. BARKER, R. PETO et al.: Maternal scrum alpha-fetoprotein in multiple pregnancy. Br. Med.J.i (1975) 651

[24] WALD, N. J., H. S. CUCKLE, J. BOREHAM et al.: Antenantal scroening in Oxford for fetal ncural tube defects. Br. J. Obstet. Gynecol. 86 (1979) 91

[25] WALD, N., H. CUCKLE, G. M. STIRRATT et al.: Maternal serum alpha-fetoprotein and low birth weight. Lancet ii (1977) 268

Federico G. Mariona, M.D. Division of Maternal-Fetal Medicine Hutzel Hospital 4707 St. Antoine Boulevard Detroit, Michigan 48201 USA 
. 